\title{
Return of State Assets Through Civil Lawsuits in Corruption Criminal Action
}

\author{
Atika Sandra Dewi ${ }^{1}$, Asrul ${ }^{1}$ \\ ${ }^{1}$ Law Faculty, Amir Hamzah University, Medan, Indonesia \\ eliakim_purba@yahoo.com
}

\begin{abstract}
The main problem to be examined is how the efforts of prosecutors as state lawyers in returning assets of state assets resulting from criminal acts of corruption through civil lawsuits and to find out the constraints in returning those assets. In this study the authors use the Normative Law research method, the Normative Law research method or the library research method is a study that studies study documents using various secondary data in the form of positive rules or norms in the legislation system. It can be concluded that the actions of the Prosecutors as investigators and public prosecutors obtained the fact that there has been a real loss of state finances and acts against the law so that it will facilitate the State Attorney in carrying out civil lawsuits. it can even be known from the beginning of the investigation that suspects, defendants and convicts possess property to recover state financial losses incurred, by preparing formal evidence and arguments known as the burden of proof in order to achieve the goal of returning state assets through civil lawsuits in criminal offenses corruption. In the process of returning assets resulting from criminal acts of corruption experienced several obstacles that were quite difficult for law enforcement officials in the process of efforts to recover state assets resulting from these criminal acts of corruption, among those obstacles were systemic corruption, abuse of power (Abuse of Power) and transformation of national law.
\end{abstract}

Keywords : state losses; civil lawsuits; prosecutors; corruption

\section{Introduction}

Corruption has always gained more attention compared to other criminal offences in various parts of the world including Indonesia. This phenomenon is understandable given the negative impact caused by this crime. The impact caused can touch various fields of life. Corruption is a serious problem, this crime can jeopardize the socio-economic development, and also politics, and can damage democratic values and morality because this action gradually becomes a culture. Corruption is a threat to the ideals of the nation towards a just and prosperous society, so this issue is very important to be heeded and is the subject of discussion by all groups. In Indonesia, the steps to form a positive law to deal with the problem of corruption have been carried out over several periods of history and through several periods of changes in legislation. The term corruption as a juridical term was only used in 1957, namely the existence of a Military Rule Regulation in force in the territory of the Land Force (Military Regulation Number PRT / PM / 06/1957).

The provisions of the criminal acts of corruption contained in the Criminal Code are considered to be less effective in anticipating or even overcoming the problem of corruption. Therefore, a law was formed to eradicate the problem of corruption, with the hope of filling and perfecting the shortcomings contained in the Criminal Code. With the enactment of Law 20 of 2001 concerning Amendments to Law Number 31 of 1991 concerning Eradication of Corruption, the provisions of Article 209 of the Criminal Code, Article 210 of the Criminal 
Code, Article 415, Article 416 of the Criminal Code, Article, 417 Criminal Code, Article 418 of the Criminal Code, Article, 419 of the Criminal Code, Article 420 of the Criminal Code, Article, 423 of the Criminal Code, and Article 425 of the Criminal Code is declared invalid.

At present, based on the facts that occur, it can be said that corruption never runs out even thrives. Marwan Effendy, said that corruption in Indonesia seems to be inexhaustible, it is increasingly being dealt with, even though its development continues to increase from year to year, both in the number of cases, the amount of state financial losses and its quality. Even the modus operandi is increasingly patterned and systematic, its scope has spread to all aspects of people's lives and across national borders, corruption nationally is agreed not only as an extraordinary crime (extra ordinary crime) and transnational crime.

\section{Review of Literature}

\subsection{State Losses}

Refunding state money or state assets resulting from corruption in its implementation feels difficult to implement because in general criminal acts of corruption both on a small scale and large scale are carried out in highly confidential, covert, involving many parties with strong solidarity to protect each other or cover up corrupt acts through legal manipulation, legal engineering, and apathetic behavior of state officials towards the people's interests. Even assets from the plunder of the corruptors have crossed the border through transfers between accounts to other countries as an anticipation and to obscure the origin of these assets ${ }^{2}$. Therefore, an extraordinary method must be carried out, namely by seizing the assets resulting from corruption. One of the fundamental elements in corruption is the loss of state finances. Consequently, the eradication of corruption does not merely aim at corruptors being sentenced to prison (detterence effect), but must also be able to recover the state losses that have been corrupted. The issue of recovering state losses (asset recovery) in the practice of handling corruption cases has become a serious problem, because based on several facts that have occurred many corruption cases have been sentenced, but in the case of the implementation of criminal substitute money is difficult to materialize. Therefore, there is a need for hard work done by State legal institutions to try to recover the state losses from the perpetrators of corruption, this can be realized with the cooperation established by various law enforcement parties to try hard to recover the state losses. Without this cooperation, it would be difficult to recover a state's loss.

The pattern of criminal acts of corruption starts with behavior or actions that are immoral, unethical, and / or violate the law for personal and / or group interests that are detrimental to state finances, in order to eradicate corruption, besides optimizing criminal law, it must also using civil law. Law No. 31/1999 concerning Eradication of Corruption Crimes that has been changed to Law No. 20/2001 concerning Eradication of Corruption, does not only provide criminal legal opportunities through confiscation of the assets of the perpetrators by investigators and the continuation of the prosecutor's prosecution demanding that judges seizing, but also providing opportunities through civil legal instruments.

According to Yanuar The return of the corrupted state finances was carried out by civil litigation, which was alternatively directed from two sources: 
A civil lawsuit is very necessary, the prosecutor as a state lawyer needs to increase the lawsuit in a civil case if the requirements for conducting a civil suit are fulfilled. The lawsuit by the prosecutor as a state attorney is certainly not just to meet the elements of the lawsuit, but also must meet formal and material requirements. In Law Number 31 of 1999 jo. Law Number 20 Year 2001 has also regulated the possibility of using civil lawsuits, namely in Article 32, Article 33, Article 34 and Article 38 letter c, in the event that the defendant or suspect dies or the prosecution cannot continue because of insufficient evidence even though there is already enough evidence state loss.

The rationale for regulating civil law in the Criminal Act of Corruption indicates that in order to recover state financial losses due to criminal acts of corruption it is not enough to only rely on norms of criminal law. If the Corruption Crime Act is categorized as a criminal law, then the regulation of civil law efforts in the Law, indicating that a statutory regulation can at the same time contain aspects of criminal law and civil law. The regulation of civil law is possible in the Corruption Act indicating that corruption is categorized as a high-level crime (extraordinary crime) in handling it required in extraordinary ways as well. Iskandar said the possibility of regulating civil lawsuits in the Corruption Act was based on the following reasons:

1. Criminal settlement of corruption cases does not always succeed in recovering state financial losses, at least in certain circumstances. The limitation of criminal law makes the criminal law instrument not the only one to solve the problem of state financial returns due to corruption;

2. Corruption as an extraordinary crime, which involves state power and loss, the way to handle it is done in an extraordinary way, namely in addition to going through criminal channels also through civil means;

3. The purpose of regulating a civil suit is intended to fulfill the sense of justice of the public against perpetrators of corruption who hide the results of corruption, then a civil suit is regulated to maximize the return of state finances. Civil lawsuits need to be placed as the main legal remedy besides criminal efforts, not merely facultative or complementary to criminal law, as stipulated in the Eradication Act. Corruption Crime. In this study, the author tries to examine further the return of state assets through civil lawsuits in criminal acts of corruption, imprisonment is not not entirely effective in overcoming the problem of corruption in Indonesia, and does not necessarily be able to recover state losses from these problems. So this matter needs to be reviewed legally related to various legal remedies concerning this issue. Of course, every institution that has authority in this matter is also expected to be able to strive so that all assets in the form of state funds that have been embezzled are returned and should be used for the benefit of the state.

Seeing these problems, then on this occasion the authors are interested in compiling scientific papers with the title "Returning State Assets Through Civil Lawsuit in Corruption".

\subsection{Corruption Crime}


The term criminal acts of corruption consists of two legal concepts, namely criminal acts and corruption. Crime and corruption are two different legal concepts, each of which has its own meaning and meaning, if the two legal concepts are combined with the term criminal act of corruption will also have different meanings and meanings. The term criminal offense is derived from the Dutch language strafbaarfeit, however there is no concept that fully explains the definition of strafbaarfeit. Therefore each legal expert gives meaning to the term strafbaarfeit according to their respective perceptions and perspectives.

Strafbaarfeit, consisting of three syllables namely, straf which is translated as a criminal and event, violation and deed.4 Strafbaarfeit can be understood as an act, event, violation or act that can or may be convicted or subject to punishment. Meanwhile also in his book, Lamintang explains the word "feit" itself in Dutch to mean "a part of reality" or "een gedeelte van de werkelijkheid", while "strafbaar" means "punishable", to literally the words " strafbaar feit "can be translated as" a part of a reality that can be punished ", which is certainly not right. What can be punished is actually humans as individuals and not reality, actions or actions. Whereas in another sense, Marpaung said that "the crime is commonly referred to as delik, which comes from the Latin language that is delictum, in law, the word baar is translated as can and may be whereas for the word feit is translated as action, German is called delict, in French called delit, and in Dutch it is called delict".

\section{Discussion}

According to Remmelink "criminal law gives primary attention to human behavior or actions, especially because human actions are the main cause of violations of the rule of law. Dutch Lawmakers differed from Lawmakers in Germany, that is they did not choose the terms 'acts' or 'acts' (handeling) but facts, '(feit - criminal acts)'. For this reason, criminal offenses should be understood as human behavior (gedragingen: which includes doing or not doing) which is done in the situations and conditions formulated therein, behavior that is prohibited by law and threatened with criminal sanctions. Literally, an asset is something that has an exchange value, capital wealth. In Minister of Finance Decree No. 225/1971, KMK No. 350/1994 and KMK No. 470/1994, state assets are immovable property (land and / or buildings) and movable property (inventory) that are purchased at the expense of the state budget and other legal acquisition, owned / controlled by government agencies, nondepartmental government agencies, agencies, excluding assets which is separated and not the wealth of the Regional Government. Meanwhile in Law No. 17/2003 on State Finance, emphasizes that "the definition of state assets includes all rights and obligations of the state that can be valued in money and everything in the form of money or goods that can be used as the property of the State".

According to Government Accounting Standards (SAP) assets are economic resources that are controlled and / or owned by the government as a result of past events and from which future economic and / or social benefits are expected to be obtained, both by the government and the community, and can be measured in money units, including non-financial resources needed to provide services to the general public and resources maintained for historical and cultural reasons. 
State assets can also be said as possessed by the state, in Law No. 1 of 2004 concerning State Treasury, Article 1 states that "goods belonging to the state are all goods that are purchased or obtained at the expense of the APBN or derived from other legitimate acquisitions.

Article 1 Law No. 17 of 2003 concerning State Finance defines "state finance is all the rights and obligations of the state that can be valued in money, as well as everything in the form of money or in the form of goods that can be owned by the state in connection with the implementation of these rights and obligations". The definition of state finance, which is defined stipulatively, is rooted in the definition of state finance in terms of objects, subjects, processes, and goals. State Finance plays an important and always related role in supporting the tasks of the government to realize the State's goals.

The definition of state finance as formulated in Article 1 of Law No. 17 of 2003 concerning State Finances implies several related state rights and obligations its finance. The government or the state in order to finance the interests of the state apparatus (routine) and society (development), are given rights such as: monopoly rights to print money the right to collect taxes, duties, excise and levies, the right to produce goods and services that are needed by the community and the right to make loans both from within and outside the country. These rights are carried out in order to realize the objectives of the state as mandated in the fourth paragraph of the opening of the 1945 Constitution and make payment for the rights of third parties who have carried out part of the tasks of the state with the approval or appointment of the government. According to Article 1 number 15 of the Law No. 15 of 2006 concerning the Supreme Audit Board affirms that "State / Regional Losses are shortages of real and certain amounts of money, securities, and goods, as a result of intentional or negligent unlawful acts". From the formulation according to Article 1 number 15 of Law No.15 of 2006 concerning the Audit Board, it can be obtained important elements contained therein, namely :

a. Weaknesses: money, securities, and goods;

b. The real and exact amount;

c. As a result of legal actions both intentionally and negligently

One element in the crime of corruption is the loss of state finances. With regard to state financial losses, both the old Corruption Law, Law No. 3 of 1971 and the new Law No. 31 of 1999 in conjunction with Law No.20 of 2001, established a policy that state financial losses must be returned or replaced by corruptors (Asset Recovery).

Asset recovery theory is a legal theory that explains the legal system of returning assets resulting from criminal acts of corruption based on the principles of social justice that provide the ability, duties and responsibilities to state institutions and legal institutions to provide protection and opportunities for individuals in the community to achieve prosperity. This theory is based on the basic principle: "Give the state what is the right of the state". The state's rights contain state obligations which are the individual's right of the people, so that the principle is equal and congruent with the principle of "give to the people what is the people's right". Corruption is an act that seizes assets, which is the right of the state so that the state loses its ability to carry out its obligations and responsibilities to improve the welfare of the community. As a result, the community loses basic rights to live prosperously. 
Proof is the presentation of legal evidence according to the law by the parties who litigate with the judge in a trial, with the aim of strengthening the truth of the argument about the legal facts that are the subject of the dispute, so that the judge obtains a basis for certainty to drop the decision. According to M. Yahya Harahap, proof is the ability of the Plaintiff or Defendant to use the evidentiary law to support and justify the legal relations and events that are postulated or disputed in the legal relationship in question.

Subekti, former Chairperson of the Republic of Indonesia Supreme Court and professor of civil law at the University of Indonesia, believes that proof is a process of how evidence is used, proposed or maintained by any applicable procedural law. The semnatara, according to Sudikno Mertokusumo, proved to contain several meanings, namely:

a. Proving in a logical sense means giving certainty that is absolute, because it applies to everyone and does not allow evidence of opponents.

b. Proving in the conventional sense means to give certainty but not absolute certainty but relative certainty which has the following levels:

1) Certainty is only based on feelings, so it is intuitive and is called conviction intime.

2) Certainty is based on reason considerations, so it is called conviction raisonee.

3) Proving in a juridical sense (in civil procedural law), is nothing but giving sufficient grounds to the judge who examined the gunammi case to provide certainty about the truth of the proposed event.

4) At the stage of case settlement in court, the evidentiary event is the most important stage to prove the truth of an event or legal relationship, or the existence of a right, which is the basis for the plaintiff to file a lawsuit in court. In the proof stage also, the defendant can use his right to refute the arguments submitted by the plaintiff. Through this evidence using the evidence, the judge will obtain the basis for making a decision in completing a case.

5) The law of proof (law of evidence) in ligitation is a very complex part in the process of ligitation. That complexity will be increasingly complicated as proving is concerned with the ability to reconstruct past events or events (past events) as a truth (truth). Although the truth sought in civil judicial proceedings, it is not absolute truth (ultimate truth), but truth that is relative or even sufficiently probable (probable), but to find even the truth that still faces difficulty.

\section{Discussion}

The efforts of the State Attorney in the effort to recover state finances due to criminal acts of corruption by preparing formal evidence and arguments known as the burden of proof, in order to achieve the goal of recovering state financial losses, the State Attorney Attorney must prove that there has actually been a state financial loss, a loss state finances as a result of or in connection with the actions of the defendant, the assets of the defendant are used to recover state financial losses.

In the process of returning assets resulting from corruption has experienced several obstacles that are quite difficult for law enforcement officials in the process of returning the 
assets of the corrupt state assets, among those constraints are systemic corruption, abuse of power (Abuse of Power) and transformation of national law.

\section{A. Book}

\section{References}

Leback, Teori-Teori Keadilan, Six Theories of Justice (Penerjemah Yudi Santoso, Bandung: Nusa Media, 2012)

Marwan Effendy, Pengadilan Tindak Pidana Korupsi, Lokakarya, Anti-korupsi bagi Jurnalis, (Surabaya, 2007),

Mahendra Oka, Kerjasama Bantuan Timbal Balik Dalam Pengembalian Aset Hasil Korupsi", (Makalah dalam Seminar Sinergi Pemberantasan Korupsi, Jakarta, Selasa 4 April 2006)

Marpaung, Tindak Pidana Penyelundupan Masalah dan Pemecahan (Jakarta: Gramedia Pustaka Utama, 1991)

Marbun \& Mahfud MD, Pokok-Pokok Hukum Administrasi Negara. Yogyakarata: Liberty, 2006)

Poerwadaminta, Kamus Besar Bahasa Indonesia Edisi Ketiga, (Jakarta:Balai Pustaka)

Remmelink, Hukum Pidana (Jakarta: PT. Gramedia Pustaka Utama, 2003)

Supatmo Eka Iskandar, Prinsip Pengembalian Keuangan Negara Akibat Tindak Pidana Korupsi Melalui Gugatan Perdata,

Subekti, Hukum Pembuktian (Jakarta: Pradnya Paramita, 1991),

Sudikno Mertokusumo, Hukum Acara Perdata Indonesia, Edisi Ke Enam (Yogyakarta: Liberty, 2002),

\section{B. Invitation Regulations}

Keputusan Menteri Keuangan No. 225/1971, KMK No. 350/1994 dan KMK No. 470/1994. Undang-Undang No. 17 Tahun 2003 Tentang Keuangan Negara

Peraturan Pemerintah No. 71 Tahun 2010 Tentang Standar Akuntansi Pemerintah.

Undang-Undang Nomor 1 Tahun 2004 tentang Pembendaharaan Negara. Undang-Undang Nomor 15 Tahun 2006 tentang Badan Pemeriksa Keuangan. 